\title{
A Question of Primary and Secondary Motives: Revisiting and Applying the Sport Tourism Framework
}

\author{
Tom Robinson and Sean Gammon
}

\begin{abstract}
The motivation(s) of the sport tourist has been a regular source of discussion within much of the sport tourism literature (Gammon and Robinson, 1997; Gibson, 1998a; Hinch and Higham, 2004; Kurtzman and Zauhar, 1995a; Standeven and De Knop, 1999). Much consideration has been paid to the interaction and influence each sport or tourism motive has upon the other. This paper discusses the complexity of combining these motives; concluding that it is unrealistic to list all the possible motivational variations, but more enlightening to suggest that a relationship exits based upon primary and secondary considerations. Using this premise, a sport tourism framework is detailed (originally outlined in 1997) which not only illustrates a tentative sport tourist typology (based upon competitiveness, recreation, activity and passivity) but also a method by which organisations can utilise, in order to identify current and future sport tourism developments. Four applications of the framework are included which demonstrate its utility with regards to general, domestic, local and sport specific profiling. Lastly it is suggested that a sport tourism index be created where countries, regions and cities can compare their current sport tourism offerings with either competitors or national/international averages.
\end{abstract}

Keywords: Sport Tourism Motivation, Synergy, Secondary Reinforcement, Consumer Typology, Sport Tourism Framework, Sport Tourism Index.

\section{Introduction}

B ack in 1997 it was first suggested that sport tourism could be categorised and better defined by adopting a consumer motivation approach (Gammon and Robinson, 1997). It was posited, albeit briefly, that sport tourism could firstly be divided into two areas of focus; differentiating between those who travel primarily for sport (sport tourists) and those where sport is perceived as a secondary consideration (tourism sport). Each section was segmented further through the use of hard and soft definitions, which differentiated between competitive and recreational considerations in sport tourism, and the secondary and incidental Clearly what was missing from the original paper was, firstly any discussion relating to

Tom Robinson Senior Lecturer Hanze Institute for Sport Studies, Hanzehogeschool, Groningen, The Netherlands, Sean Gammon Senior Lecturer Department of Tourism and Leisure, The University of Luton, United Kingdom.

components of tourism sport (all of which will be explained in more detail later in this article). theoretical perspectives which would help underpin and explain the consumer motivational approach, and secondly an example(s) of its likely application to both destinations and particular sports. Therefore this paper aims to highlight the secondary reinforcement properties of sport-related tourism and its consequent implications to sport tourist categorisation, destination profiling, tourism planning and education.

\section{Sport, Tourism and Motivation.}

When reviewing literature pertaining to sport and tourism motivation it becomes clear that the plethora of explanations offered are often dependent upon the interpretation of what constitutes motivation and in some cases whether it is important to distinguish motive from motivation (Dann, 1981). For example within the tourism literature alone it soon becomes clear that the motivation to take a vacation cannot be even partially explained as a straight forward need to take a break. Such simplistic explanations fail to take into account the cultural, sociological and psychological reasons as to why an individual feels it 
necessary to take a break, as well as failing to discover whether the motivation is based upon a need to escape from a present environment or the desire to escape to another (or indeed a combination of both). Furthermore, it is unclear whether the tourists themselves are aware as to why they are making a trip:

For some, tourist motivation results from deep, psychological needs often unrecognised by tourists themselves, whereas others equate motivation with the purpose of a trip or the choice of holiday (Sharpley, 1999: 131).

In addition, it is equally ambiguous whether motivational approaches to tourism should focus upon the expressed motives of travellers or the underlying motive which initially drives them. Therefore a tourist may express the reason for travelling as a desire to be pampered - but perhaps this need to be pampered stems from self-esteem issues caused by negative childhood experiences. To help illustrate this point, IsoAhola (1980), when describing expressed leisure needs, uses an iceberg analogy to help illustrate the layers of differing motives. The tip of the iceberg (i.e. what is visible) represents expressed motives whilst the overwhelming majority of the iceberg, which remains unseen below the waterline, accounts for the underlying motives such as those pertaining to socialisation and personality factors. Fascinating though these underlying motives may be, it is arguably unrealistic to identify all the often contradictory reasons for travel which are specific to individuals' own biographies and in any case are so deep rooted as to be practically imperceptible by those who experienced them. Unsurprisingly, therefore, tourism motives mooted in the literature tend to categorise reasons for travel as escaping from and/or escaping to particular destinations in order to experience preconceived outcomes (See Dann 1981). This has led to a variety of both similar and competing cultural, social and psychological suggestions of what drives individuals and groups to travel. For example Krippendorf (1987) lists 8 primary reasons for travel: recuperation and regeneration; compensation and social integration; escape; communication; freedom and self- determination; self-realisation; happiness and to broaden the mind.

Alternatively McIntosh and Goeldner (1990) offer 4 broader categories, which would undoubtedly encompass the more specific reasons, mentioned above, these being: physical motivators; cultural motivators; interpersonal motivators; status and prestige motivators.

Whilst Ryan $(1995,2003)$ has argued the case of utilising research in leisure motivation (based upon Beard and Ragheb 1983) in order to identify motives in tourism; these being intellectual, social, competence-mastery and stimulus-avoidance component.

It is important to point out that with all the approaches detailed above (and others elsewhere in the literature) a single motive is rarely identified as the sole reason for travel; rather there are a number of motives for travel though there may be one which takes precedence over the others. This multiple motivational position is discussed by Swarbrooke and Horner (1999) who suggest that the many reasons for travel can combine collectively:

Most people's holidays represent a compromise between their multiple motivators. Either one motivation becomes dominant or a holiday is purchased which ensures all the motivators can at least be partly satisfied. (Swarbrooke and Horner, 1999: 56).

Therefore, tourism motivational research demonstrates the myriad of conscious and sub conscious reasons for travel, which in-turn effectively illustrates the complexity of this area of study. Not only does this research account for the many causes as to why an individual may wish to take a vacation but also the often contradictory reasons for specific destination choice. Furthermore, it has been suggested that motives do not act independently; but rather combine, into collective primary and secondary tourism drives. 
Similarly sport suffers from a multitude of approaches to motivation; some of which (e.g. recuperation, escape and self-determination) are also used in tourism methodologies. However, there are also some very specific motives, which are peculiar to sport such as a need to compete, a desire to win and the opportunity to develop current skill levels (Weed and Bull, 2004). These motives tend to be linked to achievement behaviour and incorporate a number of theoretical positions including: need achievement theory, test anxiety, expectation of reinforcement, and cognitive and social cognitive approaches (for a comprehensive coverage, see Roberts, 1992). To add further complexity, motivational explanations in sport do not just focus upon the actions of the active participant but also aim to explain the motives of the sport fan. For example Wann et al (2001) has identified the 8 most common sport fans motives to be associated with, group affiliation, family, aesthetic reasons, self-esteem, economic motives, eustress, escape and entertainment. In contrast, visits to sport related attractions may be founded upon motives linked to nostalgia, pilgrimage and/or education (Gammon, 2002, 2004; Gibson, 1998b; Hinch and Higham, 2004).

As discussed above, concerning the tourismmotive literature, there will undoubtedly be differences in the expressed motives to participate (actively or passively) in sport and the underlying motives that originally led to them (Iso-Ahola, 1980). It would appear safer at this point to focus upon the basic expressed motives outlined in the literature: namely that sport participation is competitively or recreationally driven - and that such participation may be achieved through passive or active involvement. Of course this is a somewhat undemanding and simplistic synthesis of the many reasons why people are involved in sport, but nevertheless may act as a starting point to explain the primary and secondary motives of sport related travel.

Such diversity in both the sport and tourism literature illustrates the multi-faceted nature of motivation which is contextually and theoretical dependent. However, these differing theoretical approaches should be viewed as neither conflictive nor competing, but rather reliant upon the motivational focus taken. It may be useful to refer to Neulinger's (1981) comments when confronted by the definitional inconsistency and diverse research approaches found in the field of "leisure" (i.e. whether it should be defined as free time, an activity, or state of mind etc):

The primary task is not to discover what leisure is, but rather to make a decision as to which of the phenomena labelled by this term, one intends to address oneself to.' (Neulinger, 1981:26)

Perhaps the same approach should be taken with the sport and tourism motivation literature; namely that the motivational approach chosen is dependent upon the aims and objectives of the research - whether they be psychologically, sociologically or culturally driven.

\section{Motivational Synergy in Sport Tourism}

Attempting to accurately identify sport tourism motivators seems to be plagued with a number of difficulties. The complexity and copious number of motives for participating in sport and tourism are well documented. Additionally the fact that these motives change over time and cover broad and disparate areas of study further exacerbates the problem.

In a sport tourism context the multiple nature of motivators (Swarbrooke and Horner,1999) can easily be described. For example the sport tourist travelling to the Euro 2004 soccer championship may want to see their team competing, enjoy the pleasant summer weather, participate in associated cultural festivities or take advantage of the local hospitality. These combined collective motives illustrates that at this point in time it is unrealistic to identify and link up the almost countless motivational variables found in both sport and tourism. It may be wiser to take a broader view of the sport-tourism nexus by first suggesting that there exists a motivational duality which is both synergetic and reciprocal. Standeven and De Knop (1999:58) highlight this relationship by 
observing that, '...the nature of sport tourism is about an experience of physical activity tied to an experience of place.' However, Standeven and De Knop's (1999) explanation of the sporttourism relationship errs on the side of geographical theory rather than a psychological one that addresses the method by which this synergy takes place.

The idea originally proposed (Gammon and Robinson, 1997) was that the sport tourist could be categorised depending upon their primary and secondary reasons for travel. Furthermore, referring to the wider literature concerning intrinsic and extrinsic motivation, it was suggested that secondary motives had an enriching affect upon the primary ones:

Secondary reinforcement refers to a process by which an originally neutral stimulus acquires reinforcing properties through its association with a primary reinforcer. In these terms, an intrinsically motivated activity is simply one in which the reinforcement value of the goal has associatively rubbed off on the behaviour itself”. (Calder and Staw, 1974: 599)

Therefore secondary motives should not be perceived as inferior or second rate, but rather as sources of enrichment to the primary ones.
For example, whilst the primary motive maybe to play golf, the experience of playing will be reinforced by a number of contextual indicators that the environment engenders. These could include climate, scenery, social elements, the quality of the course or indeed a host of other indicators which add to the overall experience of playing golf (an experience which collectively differs from the experience back home). This example illustrates that for some individuals (in this case active sport tourists) sport tourism offers them the opportunity to experience the best of both worlds. As Ryan (2003:31) succinctly observes, 'Finding something you love to do, of course, creates both meaning and pleasure.' What could be better than to participate in your favourite activity in your favourite place - or in a place that you had always wanted to go to?

Whilst it is suggested that sport and tourism motives combine additively it is less clear to what extent they interact during the experience(s). For example, it is not known in what ways (if any) negative touristic experiences affect sport related ones and vice versa. Such questions, of course focus upon the experience rather than the motive but nevertheless generates some important considerations for both the sport tourism manager and researcher. 


\section{A Sport Tourism Framework}

Diagram 1: General overview, the original framework:

updated and modified 2004

Examples

SPORT and TOURISM

\begin{tabular}{|c|c|c|c|}
\hline \multicolumn{2}{|c|}{ Sport Tourism } & \multicolumn{2}{|c|}{ Tourism Sport } \\
\hline$\underline{\text { hard definition }}$ & $\underline{\text { soft definition }}$ & $\underline{\text { soft definition }}$ & hard definition \\
\hline $\begin{array}{c}\text { Passive or active } \\
\text { participation at a } \\
\text { competitive sporting event }\end{array}$ & $\begin{array}{l}\text { Primarily active } \\
\text { recreational participation } \\
\text { in sport }\end{array}$ & $\begin{array}{l}\text { Visitors who engage in some } \\
\text { minor form of sport or } \\
\text { leisure; their participation is } \\
\text { purely incidental }\end{array}$ & $\begin{array}{l}\text { Tourists who as a } \\
\text { secondary reinforcement } \\
\text { passively or actively } \\
\text { participate in sport }\end{array}$ \\
\hline $\begin{array}{l}\text { Olympic Games - Athens. } \\
\text { Soccer - World Cup, } \\
\text { Argentina. } \\
\text { Tennis - Wimbledon, } \\
\text { England. } \\
\text { Golf -The Masters, } \\
\text { Augusta, USA. } \\
\text { Cricket - MCG, Australia. } \\
\text { Round the world yacht } \\
\text { races. } \\
\text { K1 Martial Arts - Japan. } \\
\text { Cycling - Tour de France. } \\
\text { Ice hockey - National } \\
\text { Hockey. League (NHL), } \\
\text { Canada, USA. }\end{array}$ & $\begin{array}{l}\text { "Fun Runs" - many cities. } \\
\text { Hiking - Himalayas, } \\
\text { Nepal. } \\
\text { Skiing - Alps, Switzerland. } \\
\text { Cycling tours - The } \\
\text { Netherlands. } \\
\text { Canoeing } \\
\text { France. } \\
\text { Sports Cruises around the } \\
\text { world. } \\
\text { Golf - Golf } \\
\text { Scotland. } \\
\text { Fantasy camps: Basketball, } \\
\text { Sports Legends Fantasy } \\
\text { Camp, Texas, USA. }\end{array}$ & $\begin{array}{l}\text { This category is open to } \\
\text { interpretation and includes } \\
\text { all sport related facilities that } \\
\text { tourists encounter during } \\
\text { their stay though they } \\
\text { wouldn't necessarily } \\
\text { consider using them. This } \\
\text { category may form a catalyst } \\
\text { for other sport involvement } \\
\text { in the framework at a later } \\
\text { stage. }\end{array}$ & $\begin{array}{l}\text { Mainly based on the } \\
\text { holiday } \\
\text { centre industry. } \\
\text { Centre Parcs. } \\
\text { Eurocamp. } \\
\text { Club La Santa, Lanzarote. } \\
\text { Hotel Health and Fitness } \\
\text { clubs. } \\
\text { La Manga Club Resort, } \\
\text { Spain. } \\
\text { Beach activities } \\
\text { Volleyball. The National } \\
\text { Baseball Hall of Fame } \\
\text { and Museum; } \\
\text { Cooperstown, New York. } \\
\text { Motor sport Museum; } \\
\text { Hockenheim, Germany. }\end{array}$ \\
\hline
\end{tabular}

Diagram 1: Modification of the consumer classification framework of sport and tourism (Gammon \& Robinson 1997).

Drawing upon the observations of Swarbrooke and Horner (1999); that tourism motives are generally made up of primary and secondary reasons for travel. And that secondary motives positively affect (in terms of reinforcing properties) the primary reasons for travel (Calder and Staw, 1974), a sport tourism consumer framework can be outlined.

The main aim of the framework is to, firstly, illustrate the bisectional nature of the subject area, i.e. either from a sport or tourism base (a supposition supported in the sport tourism literature, e.g. Hinch and Higham, 2004; Gibson, 2003; Kurtzman \& Zauhar,1995b) whilst, secondly, highlighting the segmentalist structure of sport tourism in order to delineate further areas of focus. Although categorising sport tourism is not new (Gibson, 1998a ; Kurtzman and Zauhar 1997; Standeven and De Knop, 1999; Hinch \& Higham,2001), the subdivision to soft and hard categories attempts to demonstrate four distinctive sport tourist types, 
each with quite different organisational, financial and methodological implications. For example, the organisational and marketing processes within the Sport Tourism hard definition differs greatly from those utilised in the Tourism Sport hard definition. The following section introduces in a little more detail the four proposed categories.

\section{$\underline{\text { Sport Tourism }}$}

The left-hand side of the framework focuses upon Sport Tourism. This section is devoted to the analysis of individuals and/or groups of people who actively or passively participate in competitive or recreational sport, whilst travelling to and/or staying in places outside their usual environment. The qualifying criteria are that sport is the prime motivation to travel, though the touristic element may act to reinforce the overall experience.

\section{Hard Definition}

A hard definition of the sport tourist includes those individuals who actively or passively participate at a competitive sporting event. We can therefore classify a hard sport tourist as someone who specifically travels to and/or stays in places outside their usual environment for either active or passive involvement in competitive sport. In this case sport is their prime motivation for travel and would encompass participation at sporting events e.g. the Olympic Games, Football World Cup. The competitive nature of these events is the distinguishing factor.

\section{Soft Definition}

A soft definition of the sport tourist would be someone who specifically travels to and/or stays in places outside their usual environment for primarily active recreational participation in a chosen sport; for example skiing and cycling holidays. The active recreational elements are the distinguishing factors here.

\section{$\underline{\text { Tourism Sport }}$}

Tourism sport comprises persons travelling to and/or staying in places outside their usual environment and participating in, actively or passively, a competitive or recreational sport as a secondary activity. The holiday or visit being their prime motivational reason for travel. Similarly this can be broken down into two distinct categories:

\section{Hard Definition}

Here one can identify holidaymakers who use sport as a secondary enrichment to their holiday (passive or active). Competitive or noncompetitive sport may be applied, examples of which are Center Parcs, Eurocamp and beach holidays. So for these tourists whilst the holiday is their primary motivation to travel, they will also expect to participate in some sport. Therefore sport will act as a secondary reinforcement to their vacation.

\section{Soft Definition}

A soft definition of tourism sport involves visitors who as a minor part of their trip engage in some form of sport on a purely incidental basis. For example whilst visiting a seaside resort for the day they play or watch bowls (jeu de boule) or play tennis in a local park; or visitors to Cambridge (UK) may wish to punt on the river. This is deemed "soft" because their participation is purely incidental.

The framework was designed in order to first identify four distinct categories of the sport tourist (based upon primary and secondary motives) and secondly, to propose that there are a number of varying facilities and resources that each category of sport tourist would be mostly likely be drawn to. This is not to suggest that competitive sports events are only going to attract those individuals and groups whose primary motive for travel is sport, for certainly major events will attract a diverse cross section of visitor, but rather to argue that it is these sport tourists that such events are more likely to attract.

Since publishing the first article, it became clear that the original framework did not account for 
either sport tourism attractions (Gibson, 1998a) or the ever popular sports fantasy camps. Halls of fame, sport museums and stadia tours have been treated as "secondary visitor attractions" and have consequently been included in the hard "Tourism Sport" category. Of course, similar to the other categories, this is a somewhat uncomfortable generalisation, as undoubtedly some of these attractions (e.g.

Application of the Framework

Diagram 2 Application of framework-A Country profile
Noucamp in Barcelona, Baseball Hall of Fame in Cooperstown) have become primary draws for domestic and international tourism alike (Gammon, 2004; John, 2002). In contrast, sports fantasy camps can be classed, as soft Sport Tourism activities as the primary aim of these products are active recreational participation (see

Gammon, 2002).

\section{THE NETHERLANDS}

Examples

SPORT and TOURISM

\begin{tabular}{|c|c|c|c|}
\hline \multirow{2}{*}{\multicolumn{2}{|c|}{ Sport Tourism }} & \multicolumn{2}{|c|}{ Tourism Sport } \\
\hline & & oft definition & hard definition \\
\hline $\begin{array}{l}\text { Passive or active participation } \\
\text { at a competitive sporting event }\end{array}$ & $\begin{array}{c}\text { Primarily active } \\
\text { recreational participation } \\
\text { in sport }\end{array}$ & $\begin{array}{l}\text { Visitors who engage in } \\
\text { some minor form of } \\
\text { sport or leisure; their } \\
\text { participation is purely } \\
\text { incidental }\end{array}$ & $\begin{array}{c}\text { Tourists who as a } \\
\text { secondary reinforcement } \\
\text { passively or actively } \\
\text { participate in sport }\end{array}$ \\
\hline $\begin{array}{l}\text { Soccer -European \& National } \\
\text { Games, Ajax Amsterdam. } \\
\text { Tennis - World Tournament, } \\
\text { Rotterdam. } \\
\text { Skating - World Cup, Thialf, } \\
\text { Heerenveen; } \\
\text { Elfstedentocht - 200km, } 11 \\
\text { cities tour, outdoor skating } \\
\text { competition, Friesland. } \\
\text { Cycling - World Cup race, } \\
\text { Maastricht. } \\
\text { Marathon } \\
\text { Rotterdam. } \\
\text { Show Jumping - equestrian } \\
\text { events, Den Bosch. } \\
\text { Field Hockey - tournaments, } \\
\text { Amstelveen. } \\
\text { Golf - Dutch Open, Hilversum. } \\
\text { Motorcycle races - TT, Assen. } \\
\text { Motor racing - Zandvoort. } \\
\text { Sailing - International Events, } \\
\text { Medemblik. } \\
\text { Basketball - Eifel Towers, } \\
\text { Nijmegen. } \\
\text { Volleyball - Dynamo, } \\
\text { Apeldoorn. } \\
\text { Swimming -National events, } \\
\text { Eindhoven. }\end{array}$ & $\begin{array}{l}\text { Cycling - short and long } \\
\text { distance routes: north sea } \\
\text { - Den Helder. 17000km of } \\
\text { special lanes and paths. } \\
\text { Walking - Hoek of } \\
\text { Holland to Den Helder, } \\
\text { Pieterpad, Wadden Sea } \\
\text { mud walking. } \\
\text { 300km coastal walks. } \\
\text { Cruises - along many of } \\
\text { rivers and canals. } \\
\text { Watersports - water } \\
\text { skiing, } \\
\text { windsurfing, fishing can } \\
\text { all be practiced in many } \\
\text { locations. } \\
\text { Skating - indoor and } \\
\text { outdoor } \\
\text { Golf holidays, The Hague }\end{array}$ & $\begin{array}{l}\text { This category is open } \\
\text { to interpretation and } \\
\text { includes all sport } \\
\text { related facilities that } \\
\text { tourists encounter } \\
\text { during their stay, } \\
\text { though they wouldn't } \\
\text { necessarily consider } \\
\text { using them. This } \\
\text { category may form a } \\
\text { catalyst for other sport } \\
\text { involvement in the } \\
\text { framework at a later } \\
\text { stage. Netherlands } \\
\text { The to a } \\
\text { exposes tourists to } \\
\text { full range of sporting } \\
\text { facilities. }\end{array}$ & $\begin{array}{l}\text { Centre Parcs - De Eemhof, } \\
\text { Almere, Amsterdam. } \\
\text { Landal green parks } 53 \text { sites } \\
\text { in total. } \\
\text { Hotel breaks - Van der } \\
\text { Valk AMS, Golden Tulip, } \\
\text { Du Bastion, NH, ACCOR. } \\
\text { Hoseasons holiday cabins - } \\
\text { Drenthe. } \\
\text { Eurocamp, } 3 \text { parcs in total. } \\
\text { Velorama, National Bicycle } \\
\text { Museum, Nijmegen. } \\
\text { Sport museum, Olympic } \\
\text { Stadium, } \\
\text { (2005). } \\
\text { Skating Amsterdam } \\
\text { Hindeloopen. }\end{array}$ \\
\hline
\end{tabular}


Diagram 2: Application of the consumer classification framework of sport and tourism (Gammon \& Robinson 1997).

Diagram 3: Application of framework - A City profile

GRONINGEN, THE NETHERLANDS

Examples

SPORT and TOURISM

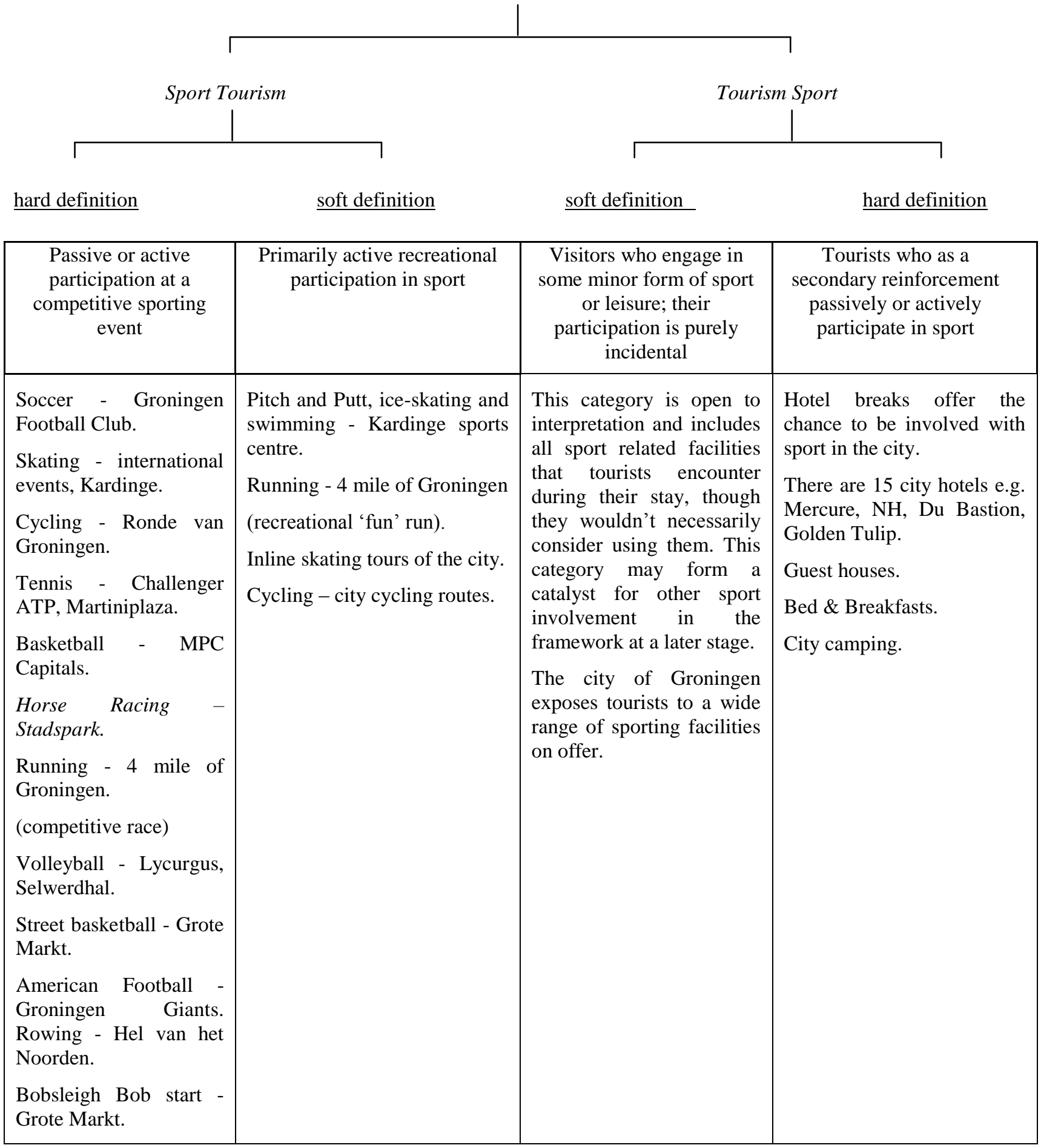

Diagram 3: Application of the consumer classification framework of sport and tourism - Groningen

Gammon \& Robinson 1997). 
Implicit in the design of the framework is its applicability to a number of motivational, planning and marketing related contexts. Sport today represents a serious consideration to national, regional and urban re-imaging and marketing strategies (Bale, 2003; Hinch and Higham, 2004; Smith, 2001). Unsurprisingly, such strategies involve a number of diverse stakeholders from both public and private sector organisations each wishing to establish and enhance their sport and tourism profiles. Indeed, since 1997 and the publication of the original article, we have been approached by local governments, major international entertainment organisations and political policy makers all interested in the applicability of the framework. It soon became apparent that further clarification and adaptation was necessary. The framework has been revisited since 1997 to provide a more international flavour of activities around the world (see figure 1) and of course to illustrate ways of how the framework could be applied to specific sports and places.

The framework can indicate the sport tourism components of a country through including major sporting, leisure and tourism activities that take place there (see figure 2). This could be based on a number of criteria. For example attendance figures, frequency, bookings, number of sports clubs, participation rates, tourism statistics or a combination of these. Similarly this principle can also be applied at a regional level (province, county or district). In addition cities and towns can also show their sport tourism and tourism sport components by the inclusion of what it has to offer through the definitions described (see figure 3 ). In this way specific sport, leisure and tourism components could be identified as potential areas to develop, or indicate areas as inadequate or weak. It may useful to refer back to Rooney's (1974) approach which helped identify a large number of hotbeds of sports activity in North America which compared regional variations with the national per capita level - as well as region to region comparisons. Cities could potentially analyse their own sport tourist numbers, local sports events or sport attractions and compare them with either the national average

(suggesting a need for a sport tourism index) or a host of other domestic and/or international urban competitors. 
GOLF

Examples

GOLF SPORT and TOURISM

\begin{tabular}{|c|c|c|c|}
\hline \multicolumn{2}{|c|}{ Golf Sport Tourism } & \multicolumn{2}{|c|}{ Golf Tourism Sport } \\
\hline hard definition & soft definition & $\underline{\text { soft definition }}$ & hard definition \\
\hline $\begin{array}{c}\text { Passive or active } \\
\text { participation at a } \\
\text { competitive sporting } \\
\text { event }\end{array}$ & $\begin{array}{l}\text { Primarily active recreational } \\
\text { participation in sport }\end{array}$ & $\begin{array}{l}\text { Visitors who engage in some } \\
\text { minor form of sport or } \\
\text { leisure; their participation is } \\
\text { purely incidental }\end{array}$ & $\begin{array}{l}\text { Tourists who as a } \\
\text { secondary } \\
\text { reinforcement passively } \\
\text { or actively participate in } \\
\text { sport }\end{array}$ \\
\hline $\begin{array}{l}\text { Ryder Cup. } \\
\text { Walker Cup. } \\
\text { USA Masters. } \\
\text { European Tour. } \\
\text { American Tour. } \\
\text { Veterans Tour. } \\
\text { Amateur Championships. } \\
\text { Dunhill Cup. } \\
\text { British } \\
\text { Championship. } \\
\text { World Matchplay. } \\
\text { Ladies Golf tournaments. } \\
\text { Junior Events. }\end{array}$ & $\begin{array}{l}\text { Golf holiday breaks, Cornwall } \\
\text { links tour, Cornwall, UK. } \\
\text { Golf complexes: } \\
\text { Hotel Tamisa Golf Fuengiro, } \\
\text { Spain. } \\
\text { Kiawah Island Golf Resort, } \\
\text { USA. } \\
\text { Vilamoura, Portugal. } \\
\text { Hotels with Golf courses: } \\
\text { The Celtic Manor resort, } \\
\text { Wales. } \\
\text { Golf Fantasy camps: Tour } \\
\text { Experience Golf Adventure, } \\
\text { Florida, USA. }\end{array}$ & $\begin{array}{l}\text { This category is open to } \\
\text { interpretation and includes } \\
\text { all golf related facilities that } \\
\text { tourists encounter during } \\
\text { their stay, though they } \\
\text { wouldn't necessarily } \\
\text { consider using them. This } \\
\text { category may form a catalyst } \\
\text { for other golf involvement in } \\
\text { the framework at a later } \\
\text { stage. } \\
\text { Examples include pitch and } \\
\text { putt, crazy golf, mini golf, } \\
\text { putting, driving ranges, } \\
\text { target golf. }\end{array}$ & $\begin{array}{l}\text { Centre Parcs. } \\
\text { Hotels near golf courses. } \\
\text { Cottage holidays with } \\
\text { golf courses nearby. } \\
\text { Holiday villa complexes } \\
\text { with golf courses. } \\
\text { Visitor Attractions: } \\
\text { Hall of Fames - World } \\
\text { Golf, Florida, USA. } \\
\text { Museums: } \\
\text { British Golf Museum, } \\
\text { St. Andrews, Scotland. }\end{array}$ \\
\hline
\end{tabular}

Diagram 4: Application of the consumer classification framework of sport and tourism - Golf (Gammon \& Robinson 1997).

Originally Published in: Journal of Sport Tourism, Volume 9 Number 3 2004, pp221-231, this article is re-published with a special permission from the authors.

The inclusion of distinct categories and through the motivational framework (see figure definitions forms a basis for exploring the 4). The sport could then be applied at any of the motives of the sport tourist, providing a levels described above. This could benefit blueprint for further analysis and investigation. particular sport organisations, national National sport and tourism agencies, local governing bodies, tour operators and of course government and private leisure companies could use this approach as a starting point for developing their portfolio of sporting products. Equally tour operators can monitor and evaluate their primary and secondary sporting products. Alternatively one sport could be analysed

The national framework example (figure 2), incorporating the Netherlands was chosen because the majority of the sport tourism literature features sporting destinations that have 
developed a relatively sophisticated sport tourism portfolio e.g. Britain, France, Portugal, Australia, USA etc. Little attention has been paid to those destinations that are not in the media limelight as either a consequence of hosting major international events or as being recognised as major tourism destinations. Similarly, sporting cities such as Barcelona, Sheffield and Sydney have been cited numerous times in the sport tourism literature (Gratton and Henry, 2001; Standeven and De Knop, 1999; Weed and Bull, 2004) at the expense of smaller, or lesser known towns.

Although, not immediately associated with sport, for a country its size the Netherlands has achieved considerable sporting success. The fervour with which the Dutch also support and follow their sports (in many ways in a carnival / party atmosphere) is second to none. However this example also serves as a reminder of the ease with which the framework can be applied to any country.

According to the Dutch Central Bureau for Statistics about $25 \%$ of the 16 million people are registered to one of the 35,000 sports clubs in the country. About two thirds of the population older than 15 years participates in sport weekly. Additionally, many Dutch enjoy watching sports events. The most popular sports, both for active participation and audience are football, cycling, speed skating and tennis. In addition in 2003 recreational activity (being away from home for at least two hours) accounted for 1 billion day trips with walking (75\% of the population) and cycling (66\%) being the most popular and on the increase. The Dutch spend about $16 \%$ of their holiday budgets in their own country. Revenues from incoming tourists account for $1.7 \%$ of the Dutch gross domestic product (GDP). This is significantly less than the European average of $2.3 \%$. The potential therefore to increase sport tourism revenue is high.

Cruises, walking holidays and cycling opportunities are popular and are well catered for. A range of water sports are also available. These range from swimming, windsurfing, sailing, water-skiing and fishing. There are many canal and river tours. With $300 \mathrm{~km}$ of coastline, walking is very popular. Walking routes are available for long and short distances and a unique experience is mud walking over the Wadden Sea to the islands offshore.

There are $17000 \mathrm{~km}$ of special cycling lanes and paths with a number of long distance routes. Bikes can be hired everywhere and railways allow bikes on trains. (www.sport.nl).

In 2003 More than $40 \%$ of day trips undertaken by children were connected with sports activities.

Choosing a city to apply the framework (figure 3 ) did not pose too much of a problem as there are a number of well-known sporting cities whose particulars are well documented (see Van Den Berg et al: 2002). But the usefulness of the framework is not just in identifying the array of existing sport tourism offerings in major urban areas but also to indicate possible future developments in $2^{\text {nd }}$ tier cities. Groningen is not a big sport tourism city, yet exemplifies effectively the dilemma many small cities face when examining their sport tourism and tourism sport profiles. They show possible gaps, over dependence and a different emphasis and perspective on the sport tourist. Groningen is the major city of the Northern Netherlands with a population of 179,000 , and is the seventh largest city in the country (www.groningen.nl). From an inspection of figure 3 it soon becomes apparent that there is further potential for Groningen to develop a sport tourism base. This is particularly emphasised by the fact that Groningen is the 'youngest' city in the Netherlands with over half the population being under thirty-five!

"Golf" was selected (figure 4) as the sport to apply to the framework because it not only illustrates well the different categories in the framework but also exhibits a range of different forms and activities. Profiling a particular sport provides an overview for possible market penetration for many organisations interested in developing a sport tourism product. 
The application of the framework provides countless opportunities to examine aspects of sport tourism at many levels. These include local, regional, national and international dimensions. However in addition different sports organisations, private companies, tour operators and local government can all utilise the flexibility of the framework to increase their understanding of the sport tourism phenomenon.

\section{Implications of the framework}

Many of the implications discussed in 1997 are unsurprisingly still relevant today. Undoubtedly the primary implication of the Sport Tourism Framework is that it attempts to delineate the sport tourist into four clearly identifiable categories based upon the combination of primary and secondary motives for travel. Consequently the framework may help to better understand the consumer through further research into the individual segments of the sport tourism categories. It also provides a starting point for profiling tourism destinations, places, cities, sports, and potentially private companies for sport tourism and tourism sport opportunities. For example, by undertaking a stock-take of what a destination currently offers in the way of sport tourism and comparing it to what is offered elsewhere, managers can either focus their efforts in maintaining and building upon what they already have or to develop particular products and services they may be weak in.

The framework continues to provide a discussion point for the future development of the subject both academically and industrially. From an academic perspective it us hoped that it will help stimulate the sport-tourism nexus debate by illustrating the breadth and diversity of the subject area. Similarly, the framework will aid sport tourism planners and managers in the innumerable opportunities open to them, as well as offering a window into both the motives and possibly the complex expectations of their customers.

\section{Conclusions}

The multitude of explanations detailing why people choose to actively or passively participate in sport, together with the many touristic motives for travel illustrates the multifacetedness of the sport tourist. In sport tourism no single motive can account for the variety of multiple and shared motives prevalent at any one time. It may be over ambitious and indeed obfuscatory to detail the almost innumerable combinations that these primary and secondary motives generate. However, it may be safer to argue that there exists a motivational and indeed experiential synergy which denotes, at a basic level, the beginning of a sport tourist typology. The Sport Tourism Framework aims to illustrate this relationship by categorising the sport tourist consumer based upon primary and secondary motives, linked to competitiveness, recreation, activity and passivity. Furthermore it also acts as an indicator to those organisations offering sport tourist experiences; outlining what they currently offer against what they might want to develop for the future.

Of course this is only a starting point to building a better understanding of the motives and experiences of the sport tourist. It is still relatively unknown in what ways sport and tourism motives combine and interact and how this might affect consumers' expectations and satisfactions. Nevertheless, the proposed framework aids in our understanding and knowledge of the sport-tourism relationship by outlining four clearly defined and applicable motivational categories. Research now needs to focus more on these categories to examine further the motives of the sport tourist and to assess in more general terms the utility of the framework.

\section{References}

Bale, J. (2003) Sports Geography, London: Routledge.

Beard, J. G. and M.G Ragheb (1983) Measuring leisure motivation. Journal Leisure Research, 15 (3), 219-28.

Calder, B.J and Staw, B. (1975) Self-perception of Intrinsic and Extrinsic. Motivation. Journal of 
Personality and Social Psychology, Vol. 31, No.4, pp. 599-605.

Dann, G.M.S. (1981) Tourist motivation: An appraisal. Annals of Tourism Research 8 (2), 187-219

Gammon, S. (2002) Fantasy, nostalgia and the pursuit of what never was. In Gammon, S. and Kurtzman, J. (Eds.) Sport Tourism: principles and practice. Eastbourne: LSA Publications.

Gammon, S. (2004) Secular Pilgrimage and Sport Tourism. In Ritchie, B. and Adair, D. (Eds.) Sport Tourism: Interrelationships, Impacts and Issues. Clevedon: Channel View Publications. pp.1-28

Gammon, S. and Robinson, T. (1997) Sport Tourism: A Conceptual Framework, Journal of Sport Tourism, Vol.4, No.3

Gibson, H. (1998a) Sport Tourism: A critical analysis of research, Sport Management Review, Vol. 1: pp.45-76

Gibson, H. (1998b). Active Sport Tourism: Who Participates? Leisure Studies, 17, 2, pp.155-170.

Gibson, H. (2003) Sport Tourism. In Parks, J.B. \& Quarterman, J.(eds) Contemporary Sport Management. Champaign, IL: Human Kinetics. 337-360

Gratton, C. And Henry, P. (eds.) (2001) Sport in the City: The role of sport in economic and social regeneration. London: Routledge.

Hinch, T. and Higham, J. (2001). Sport Tourism: A Framework for Research. The International Journal of Tourism Research, 3(1): $45-58$

Hinch, T. and Higham, J. (2004) Sport Tourism Development. Clevedon: Channel View Publications.

Iso-Ahola, S. (1980) The Social Psychology of Leisure and Recreation. Dubuque, IA: William Brown.
John, G. (2002) Stadia and Tourism. In, Gammon, S. and Kurtzman, J. (eds.) Sport Tourism: Principles and Practice. Eastbourne: LAS Publications. Pp.53-59

Krippendorf, J. (1987) The Holiday Makers. London: Heinemann

Kurtzman, J. and Zauhar, J. (1995a) Sports Tourism International Council (STIC) Research Unit. Sports Tourism Categories Revisited. Journal of Sports Tourism, Vol.2, No.3.

Kurtzman, J. and Zauhar, J. (1995b) Tourism Sport International Council. Annals of Tourism Research, Vol.22, No.3, pp.707-708

Kurtzman, J. and Zauhar, J. (1997) Wave in Time: The Sports tourism phenomenon. Journal of Sport Tourism Vol.4, No.2, pp.5-20.

McIntosh, R. and Goeldner, C. (1990) Tourism: Principles, Practices and Philosophies, New York: Wiley.

Neulinger. J. (1981) The Psychology of Leisure. Springfield, IL: Charles, C. Thomas Publisher.

Roberts, G. C. (ed.) (1992) Motivation in Sport Exercise. Leeds: Human Kinetics.

Rooney, J (1974) A Geography of American Sport: From Cabin Creek to Anaheim, Addison Wesley: Reading Mass.

Ryan, C. (1995) Researching Tourism Satisfaction: Issues, Concepts, Problems. London: Routledge.

Ryan, C. (ed.) (2003) The Tourist Experience. London: Continuum.

Sharpley, R. (1999) Tourism, Tourists and Society, Cambridge: ELM Publications.

Smith A. (2001) Sporting a New Image? Sportbased regeneration strategies as a means of enhancing the image of the city tourist destination. In Gratton, C. And Henry, P. (eds.) Sport in the City: The role of sport in economic and social regeneration. London: Routledge. 
Standeven, J. and De Knop, P. (1999) Sport Tourism. Leeds: Human Kinetics.

Swarbrooke, J \& Horner, S. (1999) Consumer Behaviour in Tourism. Oxford: Butterworth Heinemann.

Van Den Berg, L., Braun, E., Otgaar, A. (2002) Sports and City Marketing in European Cities. Hampshire: Ashgate.

Wann, D. L., Melnick, M. J., Russell, G. W., Pease, D. G. (2001) Sport Fans: The Psychology and Social Impact of Spectators. London: Routledge.

Weed, M. and Bull, C. (2004) Sports Tourism. Oxford: Butterworth- Heinemann.

www.cbs.nl Statistics Netherlands, Publication and Communications Department, Heerlen.

www.groningen.nl Official Groningen City Council website.

www.Sport.nl Netherlands Olympic Committee * Netherlands Sport Confederation (NOC*NSF 